\title{
Eicosapentaenoic Acid Enhances Skeletal Muscle Hypertrophy Without Altering the Protein Anabolic Signaling Pathway
}

\author{
SIRIGULENG ${ }^{1,2,3}$, Teruhiko KOIKE ${ }^{1,3}$, Yukie NATSUME ${ }^{1}$, Haiying JIANG ${ }^{4}$, Lan MU $^{1}$, \\ Yoshiharu OSHIDA ${ }^{1,3}$
}

${ }^{1}$ Research Center of Health, Physical Fitness and Sports, Nagoya University, Nagoya, Japan,

${ }^{2}$ Department of Physiology, Chifeng University Medical College, Chifeng, Inner Mongolia, China,

${ }^{3}$ Department of Sports Medicine, Graduate School of Medicine, Nagoya University, Nagoya, Japan,

${ }^{4}$ Department of Physiology and Pathophysiology, Jiaxing University Medical College, Jiaxing, Zhejiang, China

Received June 21, 2020

Accepted November 4, 2020

Epub Ahead of Print January 14, 2021

\section{Summary}

This study aimed to examine the effect of eicosapentaenoic acid (EPA) on skeletal muscle hypertrophy induced by muscle overload and the associated intracellular signaling pathways. Male C57BL/6] mice were randomly assigned to oral treatment with either EPA or corn oil for 6 weeks. After 4 weeks of treatment, the gastrocnemius muscle of the right hindlimb was surgically removed to overload the plantaris and soleus muscles for 1 or 2 weeks. We examined the effect of EPA on the signaling pathway associated with protein synthesis using the soleus muscles. According to our analysis of the compensatory muscle growth, EPA administration enhanced hypertrophy of the soleus muscle but not hypertrophy of the plantaris muscle. Nevertheless, EPA administration did not enhance the expression or phosphorylation of Akt, mechanistic target of rapamycin (mTOR), or S6 kinase (S6K) in the soleus muscle. In conclusion, EPA enhances skeletal muscle hypertrophy, which can be independent of changes in the AKT-mTOR-S6K pathway.

\section{Key words}

Eicosapentaenoic acid • Hypertrophy • Protein synthesis • mTOR protein

\section{Corresponding author}

T. Koike, Research Center of Health, Physical Fitness and Sports, Nagoya University, Nagoya 464-8601, Japan. Fax: 81-52-7893957. E-mail: koike@htc.nagoya-u.ac.jp

\section{Introduction}

Skeletal muscles perform important functions in both physical movements and metabolic regulation. Decline in muscle protein synthesis, increase in protein degradation, impairment of neuromuscular integrity, and metabolic disorders contribute to the loss of muscle mass strength (Cruz-Jentoft et al. 2010). Sarcopenia, which is defined as the age-related loss of muscle mass and strength, is a growing concern in the aging society. Nutrition and physical exercise can be strategically used to overcome age-related protein synthesis impairment and slow the progression of sarcopenia (Dickinson et al. 2013, Robinson et al. 2018). Skeletal muscle mass primarily depends on the dynamic relationship between protein synthesis and degradation (Schiaffino et al. 2013). Proteins and amino acids, especially branched-chain amino acids and anabolic hormones (i.e. insulin), stimulate protein synthesis; however, sarcopenia involves resistance to this system, which is called anabolic resistance (Burd et al. 2013).

Eicosapentaenoic acid (EPA) is an $\omega-3$ polyunsaturated fatty acid with various health benefits. $\omega-3$ polyunsaturated fatty acids exhibit anti-inflammatory effects and prevent cardiovascular disease (De Caterina et al. 2011, Trebaticka et al. 2017). They may exert their biological effects through the following mechanisms: release of bioactive mediators; direct effect on ion channels; direct action on membranes, which requires 
incorporation into the phospholipid layer of the plasma membrane; and activation of $\mathrm{G}$ protein-coupled receptor 120 , an $\omega-3$ polyunsaturated fatty acid receptor (De Caterina et al. 2011, Oh et al. 2011, White et al. 2014).

Supplementation with $\omega-3$ polyunsaturated fatty acids can increase muscle mass and function and exert anti-sarcopenic effects (Gray et al. 2018, Ochi et al. 2018). Supplementation with dietary $\omega-3$ fatty acids or fish oil increases muscle mass or strength (Da Boit et al. 2017, Rodacki et al. 2012, Smith et al. 2015) and muscle protein synthesis (Smith et al. 2011a, Smith et al. 2011b) in human subjects. Activation of protein anabolic signaling by $\omega-3$ polyunsaturated fatty acids has been demonstrated in steer (Gingras et al. 2007), rats (Kamolrat et al. 2013a), and $\mathrm{C} 2 \mathrm{C} 12$ myotubes (Kamolrat et al. 2013b). In contrast, McGlory recently demonstrated that fish oil supplementation suppresses resistance exercise and protein feeding-induced increase in anabolic signaling through the Akt-S6 kinase (S6K) pathway, which did not affect muscle protein synthesis in young men (McGlory et al. 2016). These data suggest the involvement of anabolic signalingdependent and anabolic signaling-independent mechanisms in the effect of EPA on muscle protein synthesis. Additionally, $\omega-3$ polyunsaturated fatty acids attenuated protein catabolism in skeletal muscles in rodents with cancer cachexia (Whitehouse et al. 2001a), sepsis (Khal et al. 2008), and arthritis (Castillero et al. 2009) and during immobilization (You et al. 2010). Furthermore, treatment with EPA or docosahexaenoic acid suppresses protein degradation in $\mathrm{C} 2 \mathrm{C} 12$ cells (Smith et al. 2005, Smith et al. 1999).

In the present study, we examined the effect of EPA on muscle protein synthesis by evaluating compensatory muscle growth in mice, which can involve multiple mechanisms (Spangenburg et al. 2009). We investigated the effect of EPA alone, whereas most previous studies had evaluated the effect of $\omega-3$ polyunsaturated fatty acids in the form of fish oil.

\section{Materials and Methods}

Animals

All experimental procedures were performed according to the Guide for the Care and Use of Laboratory Animals of Nagoya University. Male C57BL/6J mice (8 weeks of age) were obtained from Chubu Kagakushizai Co., Ltd (Nagoya, Japan). After a week of acclimation, the mice were randomly distributed into 2 groups: the control group, which was fed standard chow (Oriental Yeast Co.,
Ltd., Tokyo, Japan) containing $6 \%$ corn oil (Ajinomoto Co., Inc., Tokyo, Japan), and the EPA group, which was fed standard chow containing 6\% EPA (Mochida Pharmaceutical Co., Ltd., Tokyo, Japan). The feed was prepared daily. The mice were maintained in a $12: 12 \mathrm{~h}$ reversal light-dark environment at $23^{\circ} \mathrm{C}$ and supplied with feed and water ad libitum.

\section{Materials}

EPA ethyl ester ( $>98 \%)$ was kindly donated by Mochida Pharmaceutical Co., Ltd. We purchased primary antibodies against phospho-Akt (Ser473), phospho-S6 kinase (Ser371), and S6 kinase (49D7) from Cell Signaling Technology, Inc. (Beverly, MA, USA) and antibodies against Akt 1/2/3 (H-136) from Santa Cruz Biotechnology, Inc. (Dallas, TX, USA). Enhanced chemiluminescence (ECL) western blotting detection reagents were obtained from GE Healthcare UK Limited (Buckinghamshire, UK).

\section{Overload-induced muscle hypertrophy}

Overload-induced muscle hypertrophy is the model used to examine molecular and cellular mechanisms that regulate muscle growth (Spangenburg et al. 2009). The procedure for the overloading study is presented in Figure 1. Hypertrophic muscle growth was evaluated, as described previously (Makanae et al. 2013, Serrano et al. 2008). Briefly, mice were anesthetized using an intraperitoneal injection of sodium pentobarbital $(50 \mathrm{mg} / \mathrm{kg})$. The gastrocnemius muscle of the right hindlimb was surgically removed to induce compensatory hypertrophy of the soleus and plantaris muscles through functional overloading. An incision was made through the skin, and the Achilles tendon was exposed in the left hind legs (sham-operated), which were used as controls. After 1 or 2 weeks of overloading, the muscles and epididymal fats were dissected under anesthesia, and the mice were sacrificed. The wet weight of the muscles was measured; subsequently, the muscles were frozen in liquid nitrogen and stored at $-80{ }^{\circ} \mathrm{C}$ until analysis.

\section{Insulin tolerance test}

At 4 weeks, an insulin tolerance test (ITT) was conducted to assess global insulin sensitivity. Blood was collected from the tail tip. Mice that were fasted for $5 \mathrm{~h}$ were weighed, and insulin $(0.5 \mathrm{UI} / \mathrm{kg}$ body weight; Novorapid, Novo Nordisk A/S, Bagsvaerd, Denmark) was injected intraperitoneally. Blood glucose was measured before insulin injection and 20,40, and $60 \mathrm{~min}$ after the injection. 
1 week overloading group

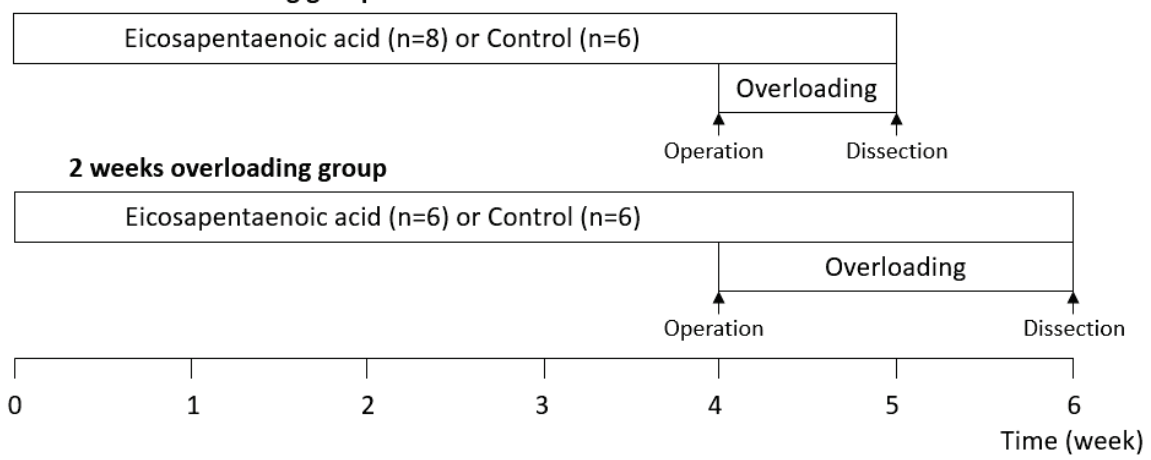

Fig. 1. The sequence of the study procedure for functional overloading.

\section{Insulin signaling in muscle}

Insulin $(0.5 \mathrm{UI} / \mathrm{kg})$ was injected intraperitoneally, and the soleus muscles were extracted after 10 min of injection. The muscles were frozen using liquid nitrogen and stored at $-80{ }^{\circ} \mathrm{C}$ until analysis.

\section{Western blotting}

The muscles were homogenized in ice-cold homogenization buffer (50 mM HEPES, pH 7.4; $150 \mathrm{mM}$ $\mathrm{NaCl} ; 1.5 \mathrm{mM} \mathrm{MgCl}_{2} ; 0.01 \%$ trypsin inhibitor; $10 \%$ glycerol, $1 \%$ Triton X-100; and $2 \mathrm{mM}$ phenylmethylsulfonyl fluoride). The lysates were incubated on ice for $1 \mathrm{~h}$ and centrifuged at $3873 \times \mathrm{g}$ for $30 \mathrm{~min}$ at $4{ }^{\circ} \mathrm{C}$. The supernatants were stored at $-20{ }^{\circ} \mathrm{C}$ until analysis. Protein concentrations in the samples were determined using a protein assay kit (Bio-Rad Laboratories Inc., Hercules, CA, USA). The lysate was solubilized in $2 \times$ loading sample buffer $(0.125 \mathrm{M}$ Tris- $\mathrm{HCl}, \mathrm{pH} 6.8 ; 10 \%$ 2-mercaptoethanol; $4 \%$ sodium dodecyl sulfate; $20 \%$ glycerol; and $0.01 \%$ bromophenol blue) and boiled at $100{ }^{\circ} \mathrm{C}$ for $5 \mathrm{~min}$. For each sample, $10 \mu \mathrm{g}$ of protein extract was separated by sodium dodecyl sulfate polyacrylamide gel electrophoresis (SDS-PAGE) at $20 \mathrm{~mA}$. The proteins were transferred to polyvinylidene difluoride membranes (EMD Millipore Corporation, Billerica, MA, USA) through semi-dry transfer at $25 \mathrm{~V}$ for $60 \mathrm{~min}$. Each membrane was blocked with $5 \%$ nonfat dry milk for $1 \mathrm{~h}$ and rinsed with $1 \times$ phosphate-buffered saline (PBS) containing $0.1 \%$ Tween 20 before the blots were incubated with a 1:1000 dilution of the primary antibodies overnight at $4{ }^{\circ} \mathrm{C}$. Subsequently, the blots were washed in $1 \times$ PBS with $0.1 \%$ Tween 20 , followed by incubation with a 1:1000 dilution of goat anti-rabbit $\operatorname{IgG}(\mathrm{H}+\mathrm{L})$-horseradish peroxidase conjugated antibody (Bio-Rad Laboratories Inc., Hercules, CA, USA) or human-serumadsorbed and peroxidase-labeled goat anti-mouse $\mathrm{IgG}$ $(\mathrm{H}+\mathrm{L})$ antibody (KPL, Gaithersburg, MD, USA) for $1 \mathrm{~h}$ at room temperature. Immunoreactive bands were detected using ECL detection reagents, and band intensity was quantified using the ImageJ densitometry software (National Institutes of Health, Bethesda, MD, USA). The individual control/overload data points were divided by the mean value for the control/overload group; thus, the mean value for the normalized control/overload group was 1 with variability. The density of the protein band for the control/sham-operated, EPA/overload, and EPA/shamoperated groups was expressed as the fold change of the density of the control/overload values (Siriguleng et al. 2018).

\section{Statistical analysis}

All values are expressed as the mean $\pm \mathrm{SD}$. Differences were analyzed using Student's unpaired or paired $t$-test or one-way analysis of variance (ANOVA) followed by Tukey's test. One-way ANOVA analysis was performed among the 4 groups (control/overload, control/sham-operated, EPA/overload, and EPA/shamoperated). Differences with $\mathrm{p}<0.05$ were considered statistically significant. All analyses were performed using GraphPad Prism 6.0 (GraphPad Software Inc., La Jolla, CA, USA).

\section{Results}

Effect of 4-week administration of EPA on body weight, muscle weight, epididymal fat, and food intake

As shown in Table 1, the food intake during the 4 weeks and the amount of epididymal fat after 4 weeks of EPA administration were lower in the EPA-administered group than in the control group. Neither body weight nor muscle weight was different between the two groups.

Effect of 4-week administration of EPA on insulin sensitivity

The fasting blood glucose level in the EPA group was significantly lower than that in the control group 
(Fig. 2a). The ITT showed that the blood glucose level 20 min after insulin injection was significantly lower in the EPA group than in the control group (Fig. 2b), suggesting that EPA administration increased systemic insulin sensitivity. However, the phosphorylation (Ser473) and protein expression of Akt in the soleus muscles after
$10 \mathrm{~min}$ of intraperitoneal insulin injection were similar between the control group and the EPA group (Fig. 2c). The Akt-mechanistic target of rapamycin (mTOR)-S6K signaling in the soleus muscles of the fasted mice was not different between the control and the EPA groups after 4 weeks of EPA administration (Fig. 3).

Table 1. Body weight, weight of muscles, and epididymal fat weight after 4 weeks of EPA administration.

\begin{tabular}{lcc}
\hline & Control (n=6) & EPA (n=7) \\
\hline Body weight (g) & $27.9 \pm 0.8$ & $27.5 \pm 0.5$ \\
Weight of muscles (mg) & & $147 \pm 8$ \\
Gastrocnemius & $146 \pm 5$ & $23.1 \pm 2.5$ \\
Plantaris & $23.4 \pm 1.5$ & $10.6 \pm 0.4$ \\
Soleus & $10.9 \pm 0.6$ & $52.9 \pm 2.6$ \\
Tibialis anterior & $50.7 \pm 2.5$ & $12.1 \pm 0.9$ \\
Extensor digitorum longus & $12.3 \pm 0.6$ & $298 \pm 78^{* * *}$ \\
Epididymal fat weight (mg) & $493 \pm 89$ & $3.47 \pm 0.09^{* * *}$ \\
Food intake per day (g/day) & $3.71 \pm 0.07$ & $101.01 \pm 2.74 * * *$ \\
Total food intake (g) & $107.58 \pm 1.91$ & \\
\hline
\end{tabular}

Data are expressed as mean \pm SD. Statistical difference vs. the Control group $(* * * p<0.001)$.

a

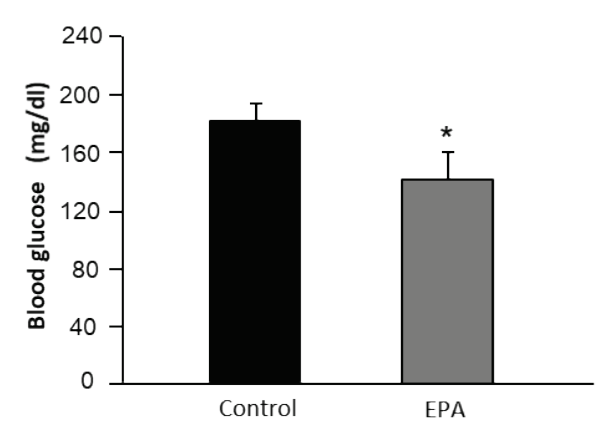

C

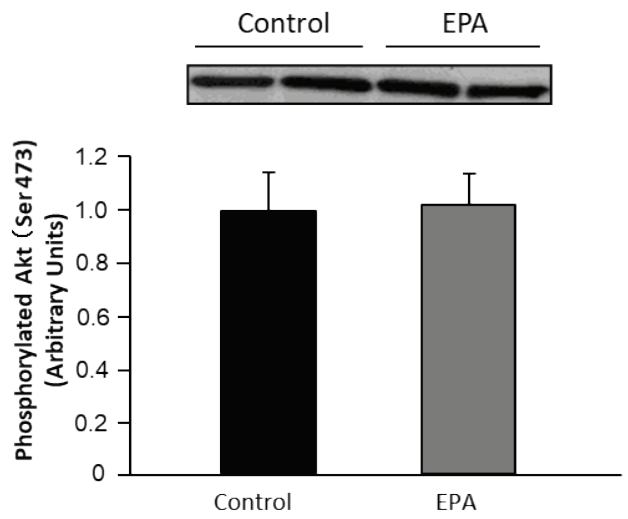

b

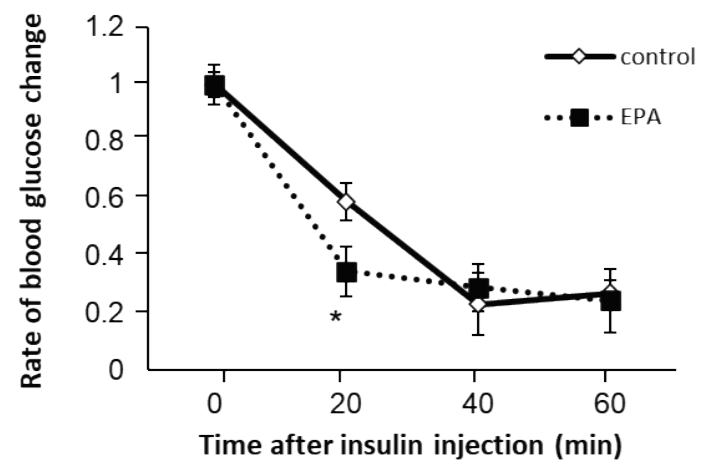

d

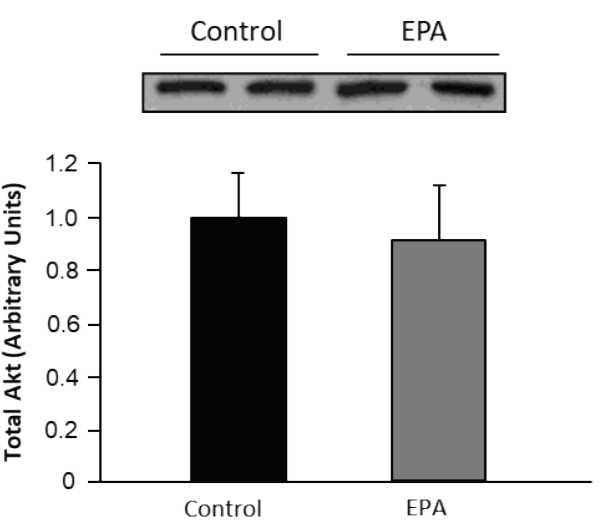

Fig. 2. Effect of EPA administration on insulin sensitivity. Fasting glucose levels after 4 weeks of EPA administration (a). Insulin tolerance test (ITT) was performed after 4 weeks of EPA administration $(* p<0.05)(\mathbf{b})$. Phosphorylation $(\mathbf{c})$ and protein expression $(\mathbf{d})$ of Akt in the soleus muscles were analyzed by western blotting. Representative immunoblots are displayed in the top panels. Control group $(n=6)$; EPA group $(n=7)$. Data are expressed as the mean \pm SD. 
a

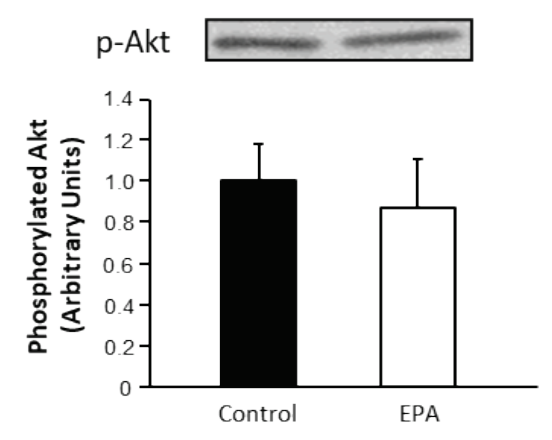

b

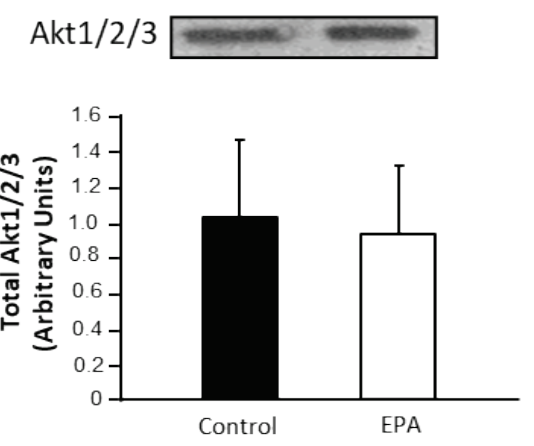

C

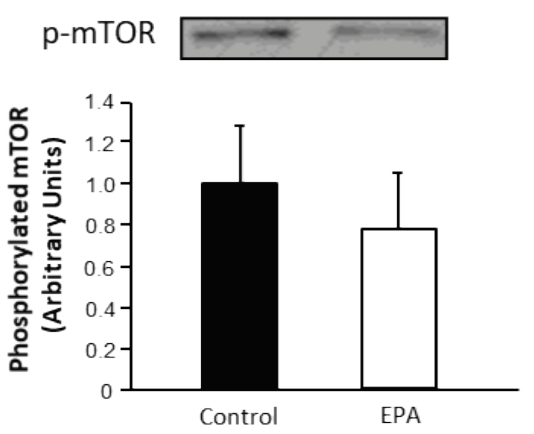

d

\section{mTOR}

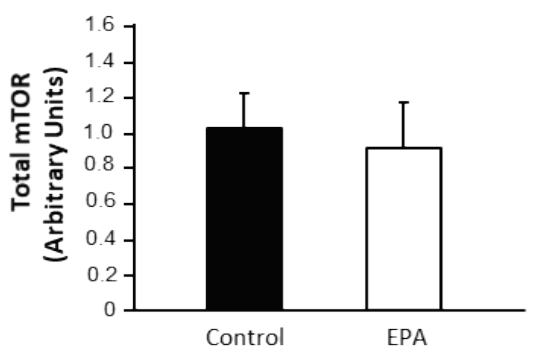

e

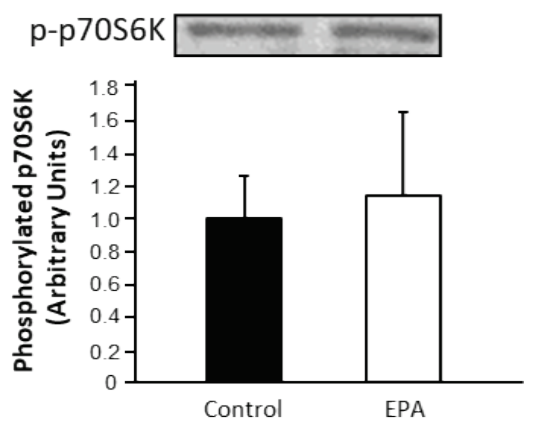

f
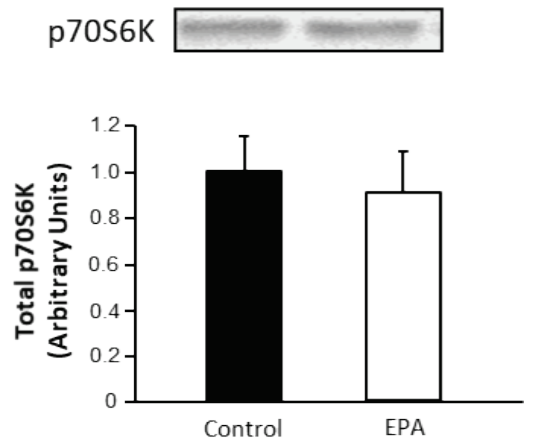

Fig. 3. Effect of EPA administration on the Akt-mTOR-S6K pathway in soleus muscles. Phosphorylation and protein expression of Akt $(\mathbf{a}, \mathbf{b}), \operatorname{mTOR}(\mathbf{c}, \mathbf{d})$, and S6K $(\mathbf{e}, \mathbf{f})$ in the soleus muscles after 4 weeks of EPA administration were analyzed by western blotting. Representative immunoblots are displayed in the top panels. Control group $(n=6)$; EPA group $(n=7)$. Data are expressed as the mean \pm $\mathrm{SD}$. The density of the protein band of the EPA groups was expressed as the fold change in the density with respect to the mean of the Control group values.

Effect of EPA on the weight of the soleus and plantaris muscles in overload-induced muscle hypertrophy

We examined the effect of EPA administration on the growth of overloaded muscles for 1 or 2 weeks. To evaluate the time course of muscle growth, we measured the muscle weights at 1 and 2 weeks of overloading. The overloaded muscles were significantly heavier than the sham-operated leg muscles in all groups for both the soleus and plantaris muscles (Fig. 4). In addition, the soleus muscles from the overloaded legs of mice in the EPA group were heavier than that in the control group at 2 weeks of overloading but not at 1 week of overloading (Fig. 4a). The plantaris muscle weight in the overloaded leg was not significantly different among the groups at both 1 and 2 weeks of overloading (Fig. 4b). Table 2 presents the changes in body weight, overloaded leg muscle weight, epididymal fat weight, and total food intake after 1 or 2 weeks of overload. Body weight, epididymal fat weight, and food intake per day were significantly lower in the EPA group than in the control group at both 1 and 2 weeks of overloading. The weights of the tibialis anterior and extensor digitorum longus muscles in the overloading leg were not significantly different among the groups at both 1 and 2 weeks of overloading.

Effect of EPA on overload-induced anabolic signaling in soleus muscle

We evaluated the skeletal muscle cell signaling pathway associated with protein synthesis in the soleus muscles. The phosphorylation (Ser473) and protein expression of Akt, mTOR, and S6K were examined (Fig. 5). The protein expression and phosphorylation of Akt (Ser473), mTOR, and S6K (Ser371) were higher in the soleus muscles of the overloaded legs, compared to that in the sham-operated legs, and were not significantly different between the control and EPA groups at both 1 and 2 weeks of overload (Fig. 5).

\section{Discussion}

The principal finding in the present study was that EPA administration can enhance muscle growth induced by muscle overload in vivo. To the best of our knowledge, this is the first report on the effects of EPA on 
compensatory muscle hypertrophy. The AKT-mTORS6K signaling pathway for protein synthesis was not affected by EPA administration. Although epidemiological studies and studies on human subjects, animal models, and skeletal-muscle cell lines indicate the role of EPA in the regulation of muscle weight, the mechanisms underlying this effect remain unclear (Gray et al. 2018, Ochi et al. 2018). a

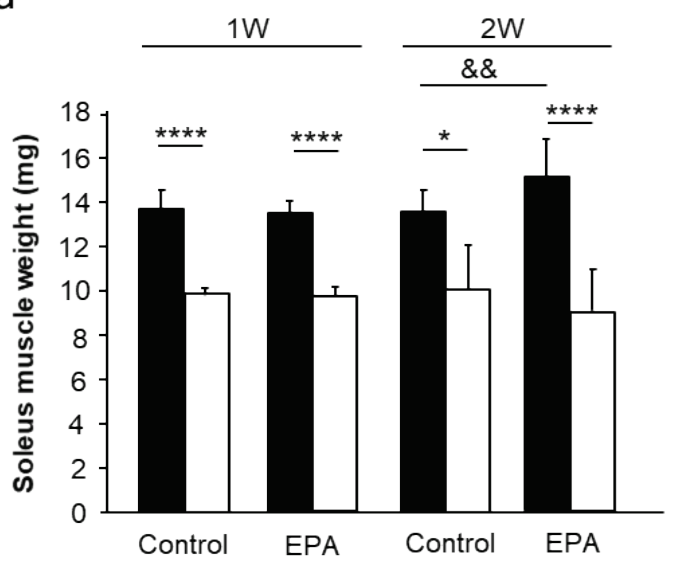

b

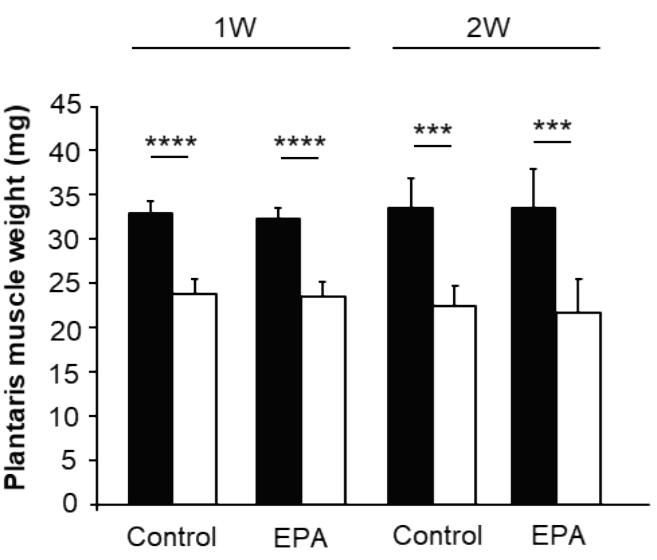

Fig. 4. Effect of EPA administration on muscle weight after 1 or 2 weeks of overloading. Weight of the soleus muscles (a) and plantaris muscles (b) of functionally overloaded legs or sham-operated legs was measured after 1 or 2 weeks of overloading. Control group ( 1 week: $n=6 ; 2$ weeks: $n=6$ ); EPA group ( 1 week: $n=8 ; 2$ weeks: $n=6) ; 1 W$, Overload of 1 week; 2W, Overload of 2 weeks. Significant differences between the overloaded and sham-operated legs in each group after 1 or 2 weeks of overloading $(* p<0.05, * * * p<0.001$, $* * * * p<0.0001)$ and between the overloaded legs in the control and EPA groups $\left({ }^{\boldsymbol{\alpha} \&} \mathrm{p}<0.01\right)$ are indicated. Statistical analysis of the differences between 1 week and 2 weeks of overloading was not performed. Data are expressed as the mean \pm SD.

Table 2. Body weight, weight of muscles, and epididymal fat weight after 1 week or 2 weeks of overloading.

\begin{tabular}{|c|c|c|c|c|}
\hline & \multicolumn{2}{|c|}{1 week of overloading } & \multicolumn{2}{|c|}{2 weeks of overloading } \\
\hline & Control $(n=6)$ & $\operatorname{EPA}(n=8)$ & Control $(n=6)$ & $\operatorname{EPA}(n=6)$ \\
\hline Body weight $(g)$ & $25.9 \pm 0.9$ & $24.8 \pm 1.0^{*}$ & $28.5 \pm 1.6$ & $26.4 \pm 0.9 * *$ \\
\hline \multicolumn{5}{|l|}{$\begin{array}{l}\text { Weight of muscles of overloaded } \\
\text { legs (mg) }\end{array}$} \\
\hline Tibialis anterior & $45.6 \pm 3.3$ & $46.1 \pm 3.7$ & $43.9 \pm 5.6$ & $47.5 \pm 2.6$ \\
\hline Extensor digitorum longus & $11.1 \pm 0.9$ & $11.2 \pm 0.7$ & $11.1 \pm 0.8$ & $10.2 \pm 0.9$ \\
\hline \multicolumn{5}{|l|}{$\begin{array}{l}\text { Weight of muscles of overloaded } \\
\text { legs (mg)/body weight (g) }\end{array}$} \\
\hline Tibialis anterior & $1.71 \pm 0.12$ & $1.84 \pm 0.13$ & $1.57 \pm 0.25$ & $1.79 \pm 0.16$ \\
\hline Extensor digitorum longus & $0.42 \pm 0.16$ & $0.45 \pm 0.15$ & $0.40 \pm 0.21$ & $0.39 \pm 0.18$ \\
\hline Epididymal fat weight (mg) & $449 \pm 13$ & $199 \pm 5 * * *$ & $309 \pm 32$ & $210 \pm 11^{* * *}$ \\
\hline $\begin{array}{l}\text { Epididymal fat weight }(\mathrm{mg}) / \text { body } \\
\text { weight }(\mathrm{g})\end{array}$ & $16.77 \pm 4.18$ & $7.91 \pm 1.79 * * *$ & $11.06 \pm 1.01$ & $7.91 \pm 0.39 * *$ \\
\hline Food intake per day (g/day) & $3.10 \pm 0.11$ & $2.96 \pm 0.15^{*}$ & $3.52 \pm 0.08$ & $3.44 \pm 0.05^{*}$ \\
\hline Total food intake $(\mathrm{g})$ & $110.29 \pm 4.79$ & $105.23 \pm 6.89$ & $148.08 \pm 3.23$ & $144.58 \pm 2.08^{*}$ \\
\hline
\end{tabular}

Data are expressed as mean \pm SD. Statistical difference vs. the Control group in 1 week or 2 weeks of overloading (*p<0.05, $* * p<0.01, * * * p<0.001)$. 
a

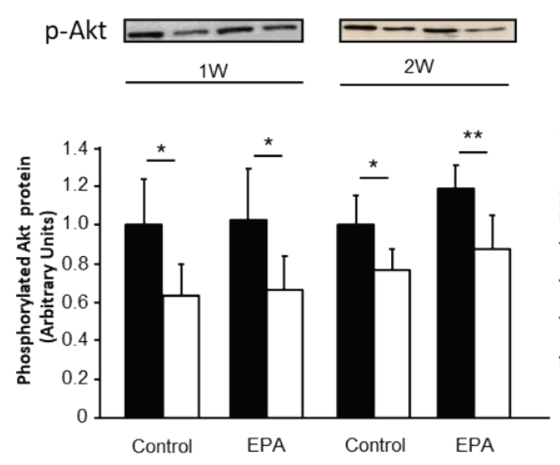

b

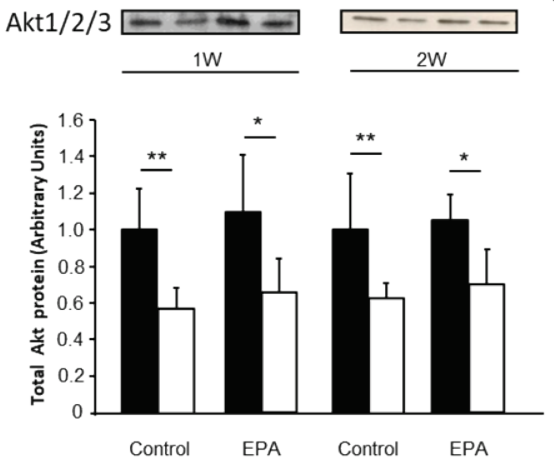

C

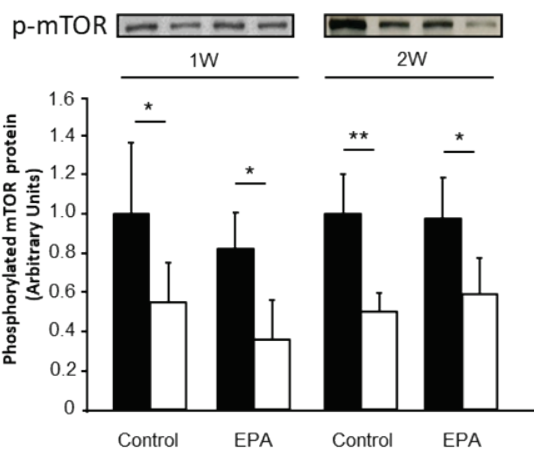

$d$
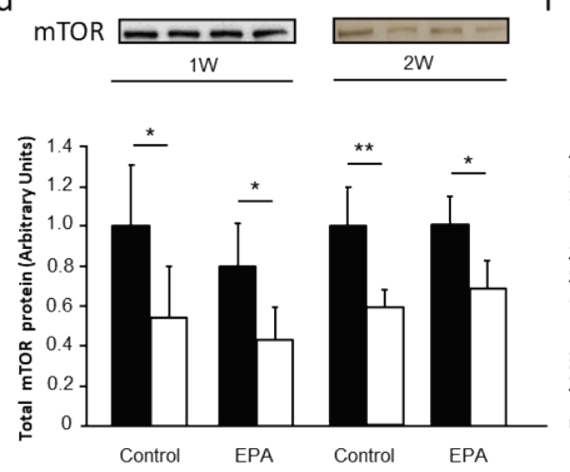

e

$f$
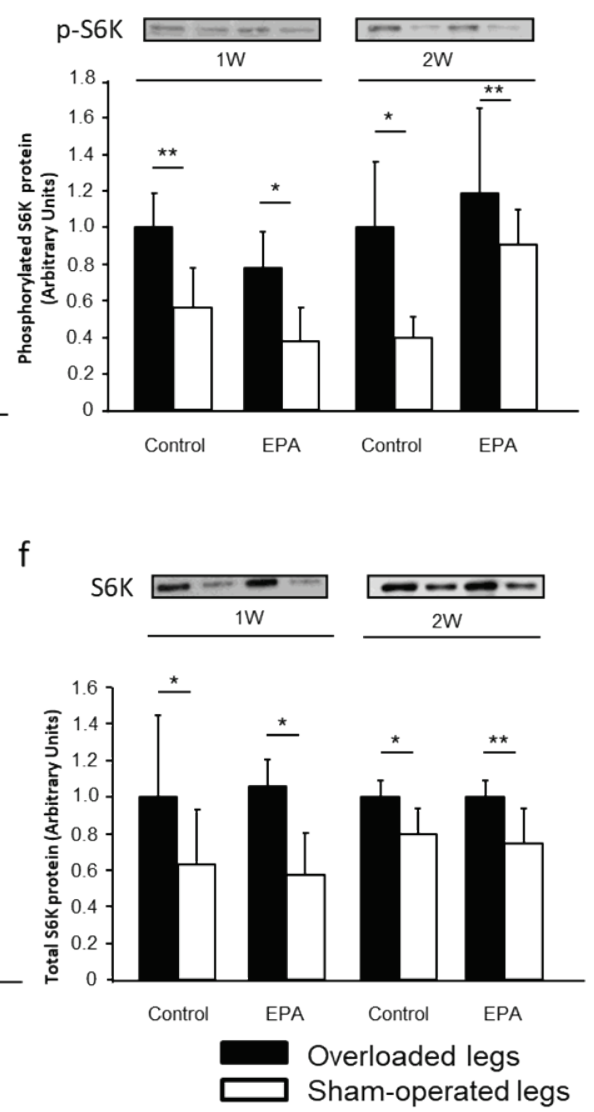

Fig. 5. Effect of EPA administration on the Akt-mTOR-S6K pathway in the soleus muscles during overloading. Phosphorylation and protein expression of Akt $(\mathbf{a}, \mathbf{b}), \operatorname{mTOR}(\mathbf{c}, \mathbf{d})$, and $\operatorname{S6K}(\mathbf{e}, \mathbf{f})$ after 1 or 2 weeks of overloading in the soleus muscles were analyzed by western blotting. Control group ( 1 week: $n=6 ; 2$ weeks: $n=6)$; EPA group ( 1 week: $n=8 ; 2$ weeks: $n=6$ ); 1 W, Overload of 1 week; 2 W, Overload of 2 weeks. Significant differences between overloaded and sham-operated legs after 1 or 2 weeks of overloading (*p<0.05, $* * p<0.01)$ are indicated. Statistical analysis of the differences between 1 week and 2 weeks of overloading was not performed. Data are expressed as the mean \pm SD.

We hypothesized that improvement in insulin sensitivity enhances muscle protein synthesis because insulin is a major anabolic hormone. The beneficial effect of $\omega-3$ fatty acids on insulin sensitivity, which improves glucose metabolism, has been reported in animal models of obesity and diabetes; however, this effect remains controversial in human studies (Lalia et al. 2016). Recently, $\omega-3$ fatty acid administration resulted in an increase in muscle protein synthesis, the anabolic response to insulin and amino acid infusion, in healthy young and middle-aged people (Smith et al. 2011b) and older adults (Smith et al. 2011a). Smith et al. additionally reported that insulin and amino acid-induced phosphorylation of AKT, mTOR, and S6K, the major signal molecules associated with skeletal-muscle protein synthesis, was enhanced after supplementation with $\omega-3$ fatty acids; neither the basal rate of muscle protein synthesis nor signaling element phosphorylation was altered in response to $\omega-3$ fatty acid administration
(Smith et al. 2011a, Smith et al. 2011b). Enhancement of amino acid-induced protein synthesis by $\omega-3$ fatty acids has also been reported in $\mathrm{C} 2 \mathrm{C} 12$ cells, with increased S6K phosphorylation (Kamolrat et al. 2013b). In the present study, the mice administered EPA for 4 weeks exhibited a decrease in fasting blood glucose levels and an improved response in the ITT compared with the control mice, which indicates that EPA improved insulin sensitivity. The following overloading experiments demonstrated enhanced muscle growth of the soleus muscle. However, phosphorylation of the signaling molecules associated with muscle protein synthesis was not altered, suggesting that the increase in soleus growth observed in the present study is not caused by the enhancement of anabolic signaling.

In catabolic states, the anti-inflammatory effects of EPA possibly have crucial functions in the reduction of muscle degradation. The role of EPA in the regulation of the ubiquitin-proteasome pathway has been demonstrated 
in pathological states such as cancer (Whitehouse et al. 2001a), starvation (Whitehouse et al. 2001b), hyperthermia (Smith et al. 2005), and sepsis (Khal et al. 2008). Administration of EPA downregulated muscle TNF- $\alpha$, which activates nuclear factor- $\kappa \mathrm{B}(\mathrm{NF}-\kappa \mathrm{B})$, the major transcription factor for the ubiquitin-proteasome pathway, in a rat model of arthritis (Castillero et al. 2009) and a mouse model of Duchenne muscular dystrophy (Machado et al. 2011). Additionally, the effects of EPA on TNF- $\alpha$, NF- $\kappa \mathrm{B}$, and the proteasome pathway have been demonstrated in $\mathrm{C} 2 \mathrm{C} 12$ myoblasts and myotubes (Smith et al. 2005, Smith et al. 1999, Huang et al. 2011, Magee et al. 2008). In the present study, we observed a lower amount of epididymal fat in the EPA group than in the control group. A lower amount of epididymal fat is associated with reduced inflammation (Sato et al. 2010, Figueras et al. 2011). However, the anti-inflammatory effect of EPA is usually observed in obese models but not in normal models (Itoh et al. 2012). Furthermore, it has been demonstrated that $\omega-3$ fatty acids can increase muscle mass in healthy people (Smith et al. 2011b) and healthy animals (Gingras et al. 2007) without activation of the catabolic system. In the present study, although the lack of inflammatory marker analysis limits our argument, it is unlikely that the anti-inflammatory effects of EPA enhanced the growth of soleus in the healthy mice.

In the present study, we observed the enhancement effect of EPA on overload-induced muscle hypertrophy only in the soleus muscle, a primarily type I muscle, but not in the plantaris muscle, a primarily type II muscle. This effect was in contrast to the effect of prior chronic aerobic exercise on overload-induced muscle hypertrophy, in which the effect was only observed in the plantaris muscle (Siriguleng et al. 2018). Type II muscles are more sensitive to the effects of various physiological and pathological conditions than type I muscles (Holecek et al. 2017, Koopman et al. 2006, Muthny et al. 2008). Thus, we hypothesized that enhanced hypertrophy through EPA administration would be observed in the plantaris muscle. We observed a significant increase or a tendency toward increase in the phosphorylation of AKT $(p<0.01)$, mTOR $(p=0.08)$, and S6K $(p=0.05)$ in the plantaris muscles of the overloaded legs in the EPA group compared to those in the control group (data not shown). These data indicate that administration of EPA potentially augments the AKT-mTOR-S6K pathway, which can be associated with increase in insulin sensitivity. However, the muscle growth of plantaris was not affected by
EPA administration, indicating that our hypothesis was not true in the present study. The AKT-mTOR-S6K pathway in the soleus muscles was not affected despite the EPA-induced enhancement in soleus muscle growth. In summary, the present results suggest that a different mechanism or signaling pathway is involved in EPA-induced muscle hypertrophy.

Compensatory muscle hypertrophy is regulated in several steps. The IGF-Akt-FoxO signaling pathway plays a major role in this type of muscle growth; however, the precise mechanisms remain to be clarified (Schiaffino et al. 2011, Schiaffino et al. 2013). The present results, which demonstrate that the AKT-mTORS6K signaling was not affected, suggest that this pathway does not play a role in enhancing soleus muscle growth. Recently, the involvement of satellite-cell recruitment and the role of IL- 6 signaling have been demonstrated (Serrano et al. 2008). Furthermore, the autophagylysosome system and ubiquitin-proteasome system need to be appropriately regulated during these processes (Schiaffino et al. 2013). These complicated systems are regulated by the intracellular signal transduction system in the skeletal muscles.

\section{Conclusions}

EPA enhances growth of the soleus muscle without affecting anabolic signaling. Although the mechanism underlying this effect remains unclear, our findings suggest that EPA or fish oil may be promising prophylactic agents against decline in physical strength in healthy people.

\section{Conflict of Interest}

There is no conflict of interest.

\section{Acknowledgements}

This study was supported in part by a Grant-in-Aid for Scientific Research from the Japanese Ministry of Education, Culture, Sports, Science and Technology (Grant No. 24500853). We thank Mochida Pharmaceutical Co., Ltd. (Tokyo, Japan) for donating the EPA. 


\section{References}

BURD NA, GORISSEN SH, VAN LOON LJ: Anabolic resistance of muscle protein synthesis with aging. Exerc Sport Sci Rev 41: 169-173, 2013. https://doi.org/10.1097/JES.0b013e318292f3d5

CASTILLERO E, MARTIN AI, LOPEZ-MENDUINA M, VILLANUA MA, LOPEZ-CALDERON A: Eicosapentaenoic acid attenuates arthritis-induced muscle wasting acting on atrogin-1 and on myogenic regulatory factors. Am J Physiol Regul Integr Comp Physiol 297: R1322-R1331, 2009. https://doi.org/10.1152/ajpregu.00388.2009

CRUZ-JENTOFT AJ, BAEYENS JP, BAUER JM, BOIRIE Y, CEDERHOLM T, LANDI F, MARTIN FC, MICHEL JP, POLLAND Y, SCHNEIDER SM, TOPINKOVA E, VANDEWOUDE M, ZAMBONI M: Sarcopenia: European consensus on definition and diagnosis: Report of the European Working Group on Sarcopenia in Older People. Age Ageing 39: 412-423, 2010. https://doi.org/10.1093/ageing/afq034

DA BOIT M, SIBSON R, SIVASUBRAMANIAM S, MEAKIN JR, GREIG CA, ASPDEN RM, THIES F, JEROMSON S, HAMILTON DL, SPEAKMAN JR, HAMBLY C, MANGONI AA, PRESTON T, GRAY SR: Sex differences in the effect of fish-oil supplementation on the adaptive response to resistance exercise training in older people: a randomized controlled trial. Am J Clin Nutr 105: 151-158, 2017. https://doi.org/10.3945/ajcn.116.140780

DE CATERINA R: n-3 fatty acids in cardiovascular disease. $\mathrm{N}$ Engl J Med 364: 2439-2450, 2011. https://doi.org/10.1056/NEJMra1008153

DICKINSON JM, VOLPI E, RASMUSSEN BB: Exercise and nutrition to target protein synthesis impairments in aging skeletal muscle. Exerc Sport Sci Rev 41: 216-223, 2013. https://doi.org/10.1097/JES.0b013e3182a4e699

FIGUERAS M, OLIVAN M, BUSQUETS S, LOPEZ-SORIANO FJ, ARGILES M: Effects of eicosapentaenoic acid (EPA) treatment on insulin sensitivity in an animal model of diabetes: Improvement of the inflammatory status. Obesity 19: 362-369, 2011. https://doi.org/10.1038/oby.2010.194

GINGRAS AA, WHITE PJ, CHOUINARD PY, JULIEN P, DAVIS TA, DOMBROWSKI L, COUTURE Y, DUBREUIL P, MYRE A, BERGERON K, MARETTE A, THIVIERGE MC: Long-chain omega-3 fatty acids regulate bovine whole-body protein metabolism by promoting muscle insulin signalling to the Akt-mTOR-S6K1 pathway and insulin sensitivity. J Physiol 579: 269-284, 2007. https://doi.org/10.1113/jphysiol.2006.121079

GRAY SR, MITTENDORFER B: Fish oil-derived n-3 polyunsaturated fatty acids for the prevention and treatment of sarcopenia. Curr Opin Clin Nutr Metab Care 21: 104-109, 2018. https://doi.org/10.1097/MCO.0000000000000441

HOLECEK M, MICUDA S: Amino acid concentrations and protein metabolism of two types of rat skeletal muscle in postprandial state and after brief starvation. Physiol Res 66: 959-967, 2017. https://doi.org/10.33549/physiolres.933638

HUANG F, WEI H, LUO H, JIANG S, PENG J: EPA inhibits the inhibitor of kappaBalpha (IkappaBalpha)/ NF-kappaB/muscle RING finger 1 pathway in $\mathrm{C} 2 \mathrm{C} 12$ myotubes in a PPARgamma-dependent manner. Br J Nutr 105: 348-356, 2011. https://doi.org/10.1017/S0007114510003703

ITOH M, SUGANAMI T, SATOH N, TANIMOTO-KOYAMA K, YUAN X, TANAKA M, KAWANO H, YANO T, AOE S, TAKEYA M, SHIMATSU A, KUZUYA H, KAMEI Y, OGAWA Y: Increased adiponectin secretion by highly purified eicosapentaenoic acid in rodent models of obesity and human obese subjects. Arterioscler Thromb Vasc Biol 27: 1918-1925, 2007. https://doi.org/10.1161/ATVBAHA.106.136853

KAMOLRAT T, GRAY SR, THIVIERGE MC: Fish oil positively regulates anabolic signalling alongside an increase in whole-body gluconeogenesis in ageing skeletal muscle. Eur J Nutr 52: 647-657, $2013 \mathrm{a}$. https://doi.org/10.1007/s00394-012-0368-7

KAMOLRAT T, GRAY SR: The effect of eicosapentaenoic and docosahexaenoic acid on protein synthesis and breakdown in murine C2C12 myotubes. Biochem Biophys Res Commun 432: 593-598, 2013 b. https://doi.org/10.1016/j.bbrc.2013.02.041

KHAL J, TISDALE MJ: Downregulation of muscle protein degradation in sepsis by eicosapentaenoic acid (EPA). Biochem Biophys Res Commun 375: 238-240, 2008. https://doi.org/10.1016/j.bbrc.2008.08.004

KOOPMAN R, ZORENC AH, GRANSIER RJ, CAMERON-SMITH D, VAN LOON LJ: Increase in S6K1 phosphorylation in human skeletal muscle following resistance exercise occurs mainly in type II muscle fibers. Am J Physiol Endocrinol Metab 290: E1245-E1252, 2006. https://doi.org/10.1152/ajpendo.00530.2005 
LALIA AZ, LANZA IR: Insulin-sensitizing effects of omega-3 fatty acids: lost in translation? Nutrients 8: $329,2016$. https://doi.org/10.3390/nu8060329

MACHADO RV, MAURICIO AF, TANIGUTI AP, FERRETTI R, NETO HS, MARQUES MJ: Eicosapentaenoic acid decreases TNF-alpha and protects dystrophic muscles of $\mathrm{mdx}$ mice from degeneration. J Neuroimmunol 232 : 145-150, 2011. https://doi.org/10.1016/j.jneuroim.2010.10.032

MAGEE P, PEARSON S, ALLEN J: The omega-3 fatty acid, eicosapentaenoic acid (EPA), prevents the damaging effects of tumour necrosis factor (TNF)-alpha during murine skeletal muscle cell differentiation. Lipids Health Dis 7: 24, 2008. https://doi.org/10.1186/1476-511X-7-24

MAKANAE Y, KAWADA S, SASAKI K, NAKAZATO K, ISHII N: Vitamin C administration attenuates overload-induced skeletal muscle hypertrophy in rats. Acta Physiol (Oxf) 208: 57-65, 2013. https://doi.org/10.1111/apha.12042

MCGLORY C, WARDLE SL, MACNAUGHTON LS, WITARD OC, SCOTT F, DICK J, BELL JG, PHILLIPS SM, GALLOWAY SD, HAMILTON DL: Fish oil supplementation suppresses resistance exercise and feedinginduced increases in anabolic signaling without affecting myofibrillar protein synthesis in young men. Physiol Rep 4: e12715, 2016. https://doi.org/10.14814/phy2.12715

MUTHNY T, KOVARIK M, SISPERA L, TILSER I, HOLECEK M: Protein metabolism in slow- and fast-twitch skeletal muscle during turpentine-induced inflammation. Int J Exp Pathol 89: 64-71, 2008. https://doi.org/10.1111/j.13652613.2007.00553.X

OCHI E, TSUCHIYA Y: Eicosapentaenoic acid (EPA) and docosahexaenoic acid (DHA) in muscle damage and function. Nutrients 10: 552, 2018. https://doi.org/10.3390/nu10050552

OH DY, TALUKDAR S, BAE EJ, IMAMURA T, MORINAGA H, FAN W, LI P, LU WJ, WATKINS SM, OLEFSKY JM: GPR120 is an omega-3 fatty acid receptor mediating potent anti-inflammatory and insulin-sensitizing effects. Cell 142: 687-698, 2011. https://doi.org/10.1016/j.cell.2010.07.041

ROBINSON SM, REGINSTER JY, RIZZOLI R, SHAW SC, KANIS JA, BAUTMANS I, BISCHOFF-FERRARI H, BRUYERE O, CESARI M, DAWSON-HUGHES B, FIELDING RA, KAUFMAN JM, LANDI F, MALAFARINA V, ROLLAND Y, VAN LOON LJ, VELLAS B, VISSER M, COOPER C: Does nutrition play a role in the prevention and management of sarcopenia? Clin Nutr 37: 1121-1132, 2018. https://doi.org/10.1016/j.clnu.2017.08.016

RODACKI CL, RODACKI AL, PEREIRA G, NALIWAIKO K, COELHO I, PEQUITO D, FEMANDES LC: Fish-oil supplementation enhances the effects of strength training in elderly women. Am J Clin Nutr 95: 428-436, 2012. https://doi.org/10.3945/ajen.111.021915

SATO A, KAWANO H, NOTSU T, OHTA M, NAKAKUKI M, MIZUGUCHI K, ITOH M, SUGANAMI T, OGAWA Y: Antiobesity effect of eicosapentaenoic acid in high-fat/high-sucrose diet-induced obesity. Importance of hepatic lipogenesis. Diabetes 59: 2495-2504, 2010. https://doi.org/10.2337/db09-1554

SCHIAFFINO S, MAMMUCARI C: Regulation of skeletal muscle growth by the IFG1-Akt/PKB pathway: insights from genetic models. Skelet Muscle 1: 4, 2013. https://doi.org/10.1186/2044-5040-1-4

SCHIAFFINO S, DYAR K A, CICILIOT S, BLAAUW B, SANDRI M: Mechanisms regulating skeletal muscle growth and atrophy. FEBS J 280: 4294-4314, 2011. https://doi.org/10.1111/febs.12253

SERRANO AL, BAEZA-RAJA B, PERDIGUERO E, JARDI M, MUNOZ-CANOVES P: Interleukin-6 is an essential regulator of satellite cell-mediated skeletal muscle hypertrophy. Cell Metab 7: 33-44, 2008. https://doi.org/10.1016/j.cmet.2007.11.011

SIRIGULENG, KOIKE T, NATSUME Y, IWAMA S, OSHIDA Y: Effect of prior chronic aerobic exercise on overload-induced skeletal muscle hypertrophy in mice. Physiol Res 67: 765-775, 2008. https://doi.org/10.33549/physiolres.933786

SMITH HJ, LORITE MJ, TISDALE MJ: Effect of a cancer cachectic factor on protein synthesis/degradation in murine C2C12 myoblasts: modulation by eicosapentaenoic acid. Cancer Res 59: 5507-5513, 1999.

SMITH HJ, KHAL J, TISDALE MJ: Downregulation of ubiquitin-dependent protein degradation in murine myotubes during hyperthermia by eicosapentaenoic acid. Biochem Biophys Res Commun 332: 83-88, 2005. https://doi.org/10.1016/j.bbrc.2005.04.097 
SMITH GI, ATHERTON P, REEDS DN, MOHAMMED BS, RANKIN D, RENNIE MJ, MITTENDORFER B: Dietary omega-3 fatty acid supplementation increases the rate of muscle protein synthesis in older adults: a randomized controlled trial. Am J Clin Nutr 93: 402-412, 2011a. https://doi.org/10.3945/ajcn.110.005611

SMITH GI, ATHERTON P, REEDS DN, MOHAMMED BS, RANKIN D, RENNIE MJ, MITTENDORFER B: Omega-3 polyunsaturated fatty acids augment the muscle protein anabolic response to hyperinsulinaemiahyperaminoacidaemia in healthy young and middle-aged men and women. Clin Sci (Lond) 121: 267-278, 2011b. https://doi.org/10.1042/CS20100597

SMITH GI, JULLIAND S, REEDS DN, SINACORE DR, KLEIN S, MITTENDORFER B: Fish oil-derived n-3 PUFA therapy increases muscle mass and function in healthy older adults. Am J Clin Nutr 102: 115-122, 2015. https://doi.org/10.3945/ajen.114.105833

SPANGENBURG EE: Changes in muscle mass with mechanical load: possible cellular mechanisms. Appl Physiol Nutr Metab 34: 328-335, 2009. https://doi.org/10.1139/H09-010

TREBATICKA J, DURACKOVA Z, MUCHOVA J: Cardiovascular diseases, depression disorders and potential effects of omega-3 fatty acids. Physiol Res 66: 363-382, 2017. https://doi.org/10.33549/physiolres.933430

WHITE PJ, MARETTE A: Potential role of omega-3-derived resolution mediators in metabolic inflammation. Immunol Cell Biol 92: 324-330, 2014. https://doi.org/10.1038/icb.2013.112

WHITEHOUSE AS, SMITH HJ, DRAKE JL, TISDALE MJ: Mechanism of attenuation of skeletal muscle protein catabolism in cancer cachexia by eicosapentaenoic acid. Cancer Res 61: 3604-3609, 2001a.

WHITEHOUSE AS, TISDALE MJ: Downregulation of ubiquitin-dependent proteolysis by eicosapentaenoic acid in acute starvation. Biochem Biophys Res Commun 285: 598-602, 2001b. https://doi.org/10.1006/bbrc.2001.5209

YOU JS, PARK MN, SONG W, LEE YS: Dietary fish oil alleviates soleus atrophy during immobilization in association with Akt signaling to S6K and E3 ubiquitin ligases in rats. Appl Physiol Nutr Metab 35: 310-318, 2010. https://doi.org/10.1139/H10-022 